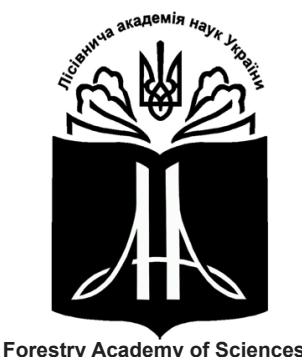

Forestry Academy of Sciences of Ukraine

Наукові праці Лісівничої академії наук України Proceedings of the Forestry Academy of Sciences of Ukraine

http://fasu.nltu.edu.ua

https://doi.org/ 411707

Article received 2017.07.12

Article accepted 2017.11.15
ISSN 1991-606X print

ISSN 2616-5015 online

(a) $\triangle$ Correspondence author Iurii Debryniuk

debrynuk_ju@ukr.net

УДК $630 * 228.7$

\title{
Технологія створення та особливості росту сосни і модрини у лісових культурах Західного Полісся
}

\author{
Ю.М. Дебринюк' , С. О. Белеля²
}

Встановлено основні технологічні елементи створення модриново-соснових культур, здійснено порівняння особливостей росту у висоту сосни звичайної та різних видів модрини в молодих насадженнях штучного походження свіжих та вологих суборів і сугрудів. Досліджено лісові культури, які ростуть на території Державного лісового фонду державних підприємств «Сарненське ЛГ», «Рівненське ЛГ» та «Соснівське ЛГ» Рівненського обласного управління лісового і мисливського господарства.

3'ясовано, щзо в 1-2-річних лісових культурах значну перевагу за висотою, порівняно із сосною звичайною, має модрина європейська (1,5-2,1 раза), а особливо - модрина широколуската (3,1 раза). У 3-річних культурах перевага модрини європейської над сосною звичайною за середньою висотою становить 1,5, за максимальним показником - 1,7 раза.

У 4-річних культурах перевага модрини над сосною за висотою у вологих суборах становить 2,0, а над сосною та ялиною у вологих сугрудах - 2,3-2,4 раза. У 5-річних лісових культурах за показником середньої висоти модрина має перевагу над сосною в 1,5-2,2, над ялиною - в 2,6-3, 6 раза.

Під час створення лісових культур використано переважно схему розміщення садивних місиь - 2,0х 1,0 м 3 розрахунку на можливий відпад модрини. Однак він виявився незначним (4-7\%), тому крок садіння для породи, враховуючи ї̈ високу інтенсивність росту, є недостатнім.

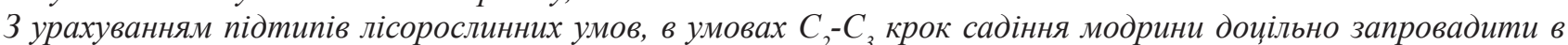
межах 1,5-2,0 м, а в умовах $B_{2}-B_{3}-1,3-1,5$ м.

Ключові слова: лісові культури 1-5-річного віку, picm у висоту, Pinus sylvestris L., Larix decidua Mill., Larix eurolepis H., Picea abies L. [Karst.]

Вступ. Модрину у лісових культурах Західного Полісся найчастіше культивують у мішаних насадженнях за участю сосни звичайної. Деревними компонентами мішаних насаджень можуть бути також дуб звичайний, ялина європейська, груша лісова, в'яз шорсткий, черешня. Рідше трапляються чисті модринові насадження $з$ природно сформованим другим ярусом із граба звичайного, липи дрібнолистої, клена гостролистого. У модринових молодняках часто трапляються береза повисла та осика природного походження, які ростуть в одному ярусі із хвойною породою.

Взаємовідносини між сосною та модриною $є$ складнішими, ніж модрини з іншими хвойними, що зумовлено подібністю біоекологічних особливостей порід. Тому деякі дослідники відзначають недоціль-

1 Дебринюк Юрій Михайлович - дійсний член Лісівничої академії наук України, академік-секретар ЛАН України, доктор сільськогосподарських наук, професор кафедри лісових культур і лісової селекції. Національний лісотехнічний університет України, вул. генерала Чупринки, 103, м. Львів, 79057, Україна. Тел.: 032-235-30-12, +38-067-195-78-36. E-mail: debrynuk_ju@ukr.net

2 Белеля Сергій Олександрович - член-кореспондент Лісівничої академії наук України, кандидат сільськогосподарських наук, директор Державного підприємства «Сарненське ЛГ» Рівненського обласного управління лісового і мисливського господарства, вул. Гоголя, 34 , м. Сарни, 34500, Україна. Тел.: +38-03655-336-69,+38-03655-355-21; E-mail: sarnylis@sowa.com.ua 
ність сумісного вирощування модрини та сосни у лісових культурах (Parakin \& Mosina, 1988, Pisarenko \& Merzlenko, 1990).

Поряд 3 цим, результати інших досліджень підтверджують доцільність культивування модриново-соснових насаджень, у складі яких модрина займає 15-25\%. Отримані дані свідчать про кращий ріст сосни у модриново-соснових, ніж у чистих соснових культурах (Debryniuk, 2003, 2013). Доцільність введення модрини у соснові деревостани підтверджується також позитивним впливом породи на грунт та високою біотичною стійкістю мішаних насаджень із цих порід (Yanushko \& Zabello, 1969).

Беручи до уваги необхідність підвищення фактичної продуктивності лісових насаджень до потенційного рівня, підвищення біотичної стійкості соснових насаджень, введення обмеженої кількості модрини у насадження Західного Полісся є актуальною проблемою.

Важливо встановити, за яких умов модрина має перевагу над сосною за таксаційними показниками, насамперед - за висотою. Ця умова $є$ найважливішою в аспекті встановлення доцільності культивування модрини у лісових насадженнях Західного Полісся. За умови відсутності такої переваги над сосною культивування модрини в цьому регіоні може бути визнано недоцільним.

Встановлено (Belelia, 2012, 2013), що серед штучних насаджень за участю модрини у Західному Поліссі переважають молоді культури до 10-річного віку, а трохи менші площі займають середньовікові насадження (41-50 років).

Об'скти та методика досліджень. Об ' $\epsilon$ 'm дослідження - штучні насадження за участю Pinus sylvestris L. та видів роду Larix L. у зв'язку з технологією їх створення та вирощування в умовах Західного Полісся України.

Предмет дослідження - технологічні елементи створення та особливості росту головних і супутніх порід в 1-5-річних лісових культурах.

Мета досліджень - встановити основні технологічні елементи створення модриново-соснових культур і порівняти особливості росту у висоту сосни звичайної та різних видів модрини в молодих насадженнях штучного походження.

Вивчали лісові культури, які ростуть на території держлісфонду державних підприємств «Сарненське ЛГ», «Рівненське ЛГ» та «Соснівське ЛГ» Рівненського ОУЛМГ. Досліджені насадження культивують у свіжих та вологих суборах і сугрудах. Головними породами в них є сосна звичайна (Pinus sylvestris L.), модрина європейська (Larix decidua Mill.), модрина широколуската або гібридна (Larix eurolepis H.), супутньою - ялина європейська (Picea abies L. [Karst.]).

Для вивчення лісівничо-таксаційних характеристик деревних порід у лісових культурах використовували загальноприйняті методики лісівничотаксаційних досліджень для лісівництва та лісової таксації (Grom, 2005, Girs et al., 2013, Miroshnikov et al., 1980).
Для визначення приживлюваності деревних видів у 1-3-річних лісових культурах на відповідних площах закладали 2-3 пробні ділянки, які мали форму витягнутих прямокутників, охоплювали не менше двох повних циклів схеми змішування і рівномірно розміщались на ділянці. Під час досліджень використовували положення чинної Інструкції з оцінки якості лісокультурних об'єктів (Instruction, 2010).

Тип лісорослинних умов і тип лісу визначали за методикою типологічних досліджень D. Vorobiev and B. Ostapenko (1979), B. Ostapenko and V. Tkach (2002) 3 використанням напрацювань Z. Gerushynsky (1987). На основі характеристик складу та продуктивності деревного ярусу, складу підліску, трав'яного вкриття, типу грунту, уточнювали тип і підтип лісорослинних умов, а також тип лісу для кожної пробної ділянки (Gorshenyn \& Buteyko, 1962).

Експериментальні матеріали досліджень статистично опрацьовано згідно з прийнятими рекомендаціями (Goroshko, Myklush, \& Khomyuk, 2004, Dospekhov, 1979) із використанням програмного забезпечення кафедри лісової таксації та лісовпорядкування НЛТУ України. Для характеристики варіаційних рядів використано показники асиметрії та ексцесу, а приналежність чисельностей до нормального розподілу визначали за критерієм достовірності: $\mathrm{t}=\mathrm{A}$ / $\mathrm{m}_{\mathrm{A}}>3$ та $\mathrm{t}=\mathrm{E} / \mathrm{m}_{\mathrm{E}}>3$.

Під час статистичного опрацювання застосовували методи варіаційної статистики і пакет програм Microsoft Excel.

Результати та обговорення. Досліджені лісові культури модрини 1-3-річного віку створювали чистими за складом 3 початковою густотою переважно 5 тис. шт./га. Висаджування деревних рослин здійснювали під меч Колесова у борозни, утворені під час обробітку грунту агрегатом МТЗ-82 + ПКЛ-70. Приживлюваність хвойної породи в культурах становила 93-96\%. Проведені агротехнічні догляди забезпечили високу збережуваність модрини та іiі значні висотні прирости. На низці пробних ділянок (ПД-14, 16, 17, 18, 12.1) заклали плантаційні лісові культури, які у 2-річному віці доповнили 1-річними сіянцями із закритого грунту. Для порівняння інтенсивності росту модрини і сосни, на двох площах заклали пробні ділянки в 1-річних лісових культурах сосни звичайної (табл. 1).

На момент проведення осінньої інвентаризації встановлено достатньо високу збережуваність порід в усіх насадженнях, яка є суттєво вищою від показника нормативної приживлюваності для культур 1-2-річного (92\%) і 3-річного віку (88\%) для Рівненської та Волинської областей (Instruction, 2010).

Найхарактернішим таксаційним показником стану лісових культур у 1-3-річному віці є їхня висота, яку відносно легко визначити (табл. 2). Середня висота залежить, насамперед, від типу лісу, віку та виду деревної рослини. Так, серед 1-річних культур найбільшим показником середньої висоти відзначається Larix eurolepis (46,4 cм), найменшим - Pinus sylvestris $(14,7$ та 15,0 см). 
Технологічні елементи створення 1-3-річних лісових культур

\begin{tabular}{|c|c|c|c|c|c|c|c|}
\hline $\begin{array}{l}\text { № } \\
\text { ПД }\end{array}$ & $\begin{array}{c}\text { Індекс } \\
\text { деревного } \\
\text { виду }\end{array}$ & $\begin{array}{l}\text { Вік, } \\
\text { років }\end{array}$ & $\begin{array}{c}\text { Початковий } \\
\text { склад; індекс } \\
\text { типу лісу }\end{array}$ & $\begin{array}{c}\text { Схема } \\
\text { змішування }\end{array}$ & $\begin{array}{c}\text { Розташування } \\
\text { садивних місць, } \\
\text { м х м; густота, } \\
\text { шт./га } \\
\end{array}$ & $\begin{array}{l}\text { Приживлюва- } \\
\text { ність, \% }\end{array}$ & $\begin{array}{c}\text { Місце розташування } \\
\text { та площа лісових культур }\end{array}$ \\
\hline 14 & Мдє & 1 & $\begin{array}{l}10 \mathrm{M} д \epsilon ; \\
B^{C} \text { з- } \partial C\end{array}$ & $\begin{array}{c}\text { чисті } \\
\text { ряди Мдє }\end{array}$ & $\begin{array}{c}2,0 \times 1,0 \\
5000\end{array}$ & 96 & $\begin{array}{c}\text { Костянтинівське л-во; кв. 61, } \\
\text { вид. 9.21, пл. 1,2 га }\end{array}$ \\
\hline 15 & Сзв & 1 & $\begin{array}{l}10 \mathrm{C} 3 \mathrm{~B} \\
B_{3}-\partial C\end{array}$ & $\begin{array}{c}\text { чисті } \\
\text { ряди Сзв }\end{array}$ & $\begin{array}{l}2,0 \times 0,7 \\
\quad 7100\end{array}$ & 95 & $\begin{array}{c}\text { Костянтинівське л-во; кв. 61, } \\
\text { вид. 9.20, пл. 0,8 га }\end{array}$ \\
\hline 16 & Мдє & 1 & $\begin{array}{l}10 \mathrm{M} \text { де; } \\
C_{3}-2 Д\end{array}$ & $\begin{array}{c}\text { чисті } \\
\text { ряди Мдє }\end{array}$ & $\begin{array}{l}2,0 \times 1,0 \\
5000\end{array}$ & 95 & $\begin{array}{c}\text { Костянтинівське л-во; кв. } 31 \text {, } \\
\text { вид. } 15, \text { пл. } 0,8 \text { га }\end{array}$ \\
\hline 17 & Мдг & 1 & $\begin{array}{l}10 \mathrm{M} д г ; \\
C_{3}^{4}-2 Д\end{array}$ & $\begin{array}{l}\text { чисті } \\
\text { ряди Мдг }\end{array}$ & $\begin{array}{l}2,0 \times 1,0 \\
5000\end{array}$ & 94 & $\begin{array}{c}\text { Костянтинівське л-во; кв. } 31 \text {, } \\
\text { вид. } 16, \text { пл. } 0,1 \text { га }\end{array}$ \\
\hline 18 & Мдє & 1 & $\begin{array}{l}10 \mathrm{M} д \epsilon ; \\
C_{2}-2-\partial C\end{array}$ & $\begin{array}{c}\text { чисті } \\
\text { ряди Мдє }\end{array}$ & $\begin{array}{l}2,0 \times 1,0 \\
5000\end{array}$ & 95 & $\begin{array}{c}\text { Костянтинівське л-во; кв. 61, } \\
\text { вид. 13, пл. 0,6 га }\end{array}$ \\
\hline 19 & $\mathrm{C}_{3 \mathrm{~B}}$ & 1 & $\begin{array}{l}10 \mathrm{C} 3 \mathrm{~B} \\
\mathrm{~B}_{2}-\partial C\end{array}$ & $\begin{array}{c}\text { чисті } \\
\text { ряди Сзв }\end{array}$ & $\begin{array}{l}2,0 \times 0,7 \\
7100\end{array}$ & 96 & $\begin{array}{c}\text { Костянтинівське л-во; кв. 36, } \\
\text { вид. 13, пл. 2,3 га }\end{array}$ \\
\hline 12 & Мдє & 2 & $\begin{array}{l}10 \mathrm{M} д е ; \\
C_{3}-2-\partial C\end{array}$ & $\begin{array}{c}\text { чисті } \\
\text { ряди Мдє }\end{array}$ & $\begin{array}{l}2,0 \times 0,5 \\
10000\end{array}$ & 93 & $\begin{array}{c}\text { Костянтинівське л-во; кв. 49, } \\
\text { вид. } 22, \text { пл. 1,3 га }\end{array}$ \\
\hline 12.1 & Мдє & 3 & $\begin{array}{l}10 \mathrm{M} д \epsilon ; \\
C_{3}-2-\partial C\end{array}$ & $\begin{array}{c}\text { чисті } \\
\text { ряди Мдє }\end{array}$ & $\begin{array}{l}2,0 \times 0,5 \\
10000\end{array}$ & 95 & $\begin{array}{c}\text { Костянтинівське л-во; кв. 49, } \\
\text { вид. } 22, \text { пл. } 1,3 \text { га }\end{array}$ \\
\hline 13 & C3B & 3 & $\begin{array}{l}10 \mathrm{C} 3 \mathrm{~B} \\
C_{3}-2-\partial C\end{array}$ & $\begin{array}{c}\text { чисті } \\
\text { ряди Сзв }\end{array}$ & $\begin{array}{l}2,0 \times 0,7 \\
7100\end{array}$ & 92 & $\begin{array}{c}\text { Костянтинівське л-во; кв. 49, } \\
\text { вид. } 19, \text { пл. 0,3 га }\end{array}$ \\
\hline
\end{tabular}

Примітка. 1. Пробні ділянки закладено у лісовому фонді Костянтинівського л-ва ДП «Сарненське ЛГ».

2. На пробній ділянці № 12.1 приживлюваність підвищилась внаслідок доповнення лісових культур

Потрібно зазначити, що модрина європейська росте дещо менш інтенсивно, ніж модрина широколуската. Так, в умовах вологого та свіжого сугруду на фоні повної подібності технологічних елементів створення лісових культур іiі середня висота на трьох пробних ділянках змінюється в межах 23,4-32,0 cм, що може бути пов'язано із фізико-хімічними властивостями грунтів та підгрунтя.

В умовах вологого сугруду (ПД-12) створено плантаційні лісові культури, де у 2-річному віці модрина досягла значного показника середньої висоти (70,5 см) за максимальної висоти 1,2 м. У 3-річному віці показник середньої висоти зростає до 109 см за максимального значення 1,95 м.

Для порівняння інтенсивності росту сосни та модрини, поряд $з$ цією ділянкою за подібною технологію в такому ж типі лісорослинних умов створено культури сосни звичайної. Проте, їхня середня висота у 3-річному віці є суттєво меншою, ніж у модрини, так само як і максимальне значення висоти (див. табл. 2). При цьому середня висота сосни у 3-річному є подібною до такої у модрини у 2-річному віці.

Розмах варіації за висотою є значним для модрини практично на всіх пробних ділянках, що свідчить, вірогідно, про генетичну неоднорідність садивного матеріалу, а також певну відмінність у фізикохімічних властивостях грунтів. Для сосни звичайної, інтенсивність росту якої є суттєво нижчою, розмах варіації значень за висотою є значно меншим.

Середній квадрат відхилень варіант від середньої величини (дисперсія) $є$ найвищим у модрини як породи найбільш швидкорослої, для якої характерний найбільший розмах варіації. Коефіцієнт варіації свідчить про значну мінливість висоти як у сосни, так і модрини. Проте у всіх випадках однорідність вибірки збережена, оскільки коефіцієнт варіації $є$ меншим ніж 50\% (22,8-38,6\%).

Незважаючи на значну мінливість висоти деревних рослин, показник точності досліду є достатньо високим (1,4-2,9\%). У межах довірчого інтервалу із заданою ймовірністю знаходяться показники висоти досліджуваних порід.

Крива, що характеризує висоту модрини, має сильну або помірну лівосторонню асиметрію, характеризується помірною або сильною крутістю і $\epsilon$ переважно туповершинною.

Висоти сіянців сосни характеризуються кривою нормального розподілу $(\mathrm{t}<3)$, а модрини - лише на пробах 17, 12, 12.1. На інших пробних ділянках розподіл чисельностей не підлягає нормальному розподілу внаслідок генетико-морфологічної неоднорідності садивного матеріалу.

Розподіл дерев модрини і сосни за групами висот підтверджує значну перевагу модрини над сосною за показником висоти в 1-річному віці (рис. 1).

Так, майже $80 \%$ саджанців сосни звичайної входить до висотної групи 11-20 см, тоді як у модрини європейської переважна більшість рослин належить до висотних груп 21-30 (37\%) та 31-40 $(25 \%)$ см, а в модрини широколускатої - до висотних груп $31-40(20 \%), 41-50(29 \%)$ та 51-60 $(19 \%)$ cм.

Вагомим показником приживлюваності порід у лісових культурах $€$ їх висотний річний приріст. Тому поряд 3 показниками середньої висоти в 1-3-річних культурах, досліджували і величину їхнього висотного приросту впродовж останнього року (табл. 3). 


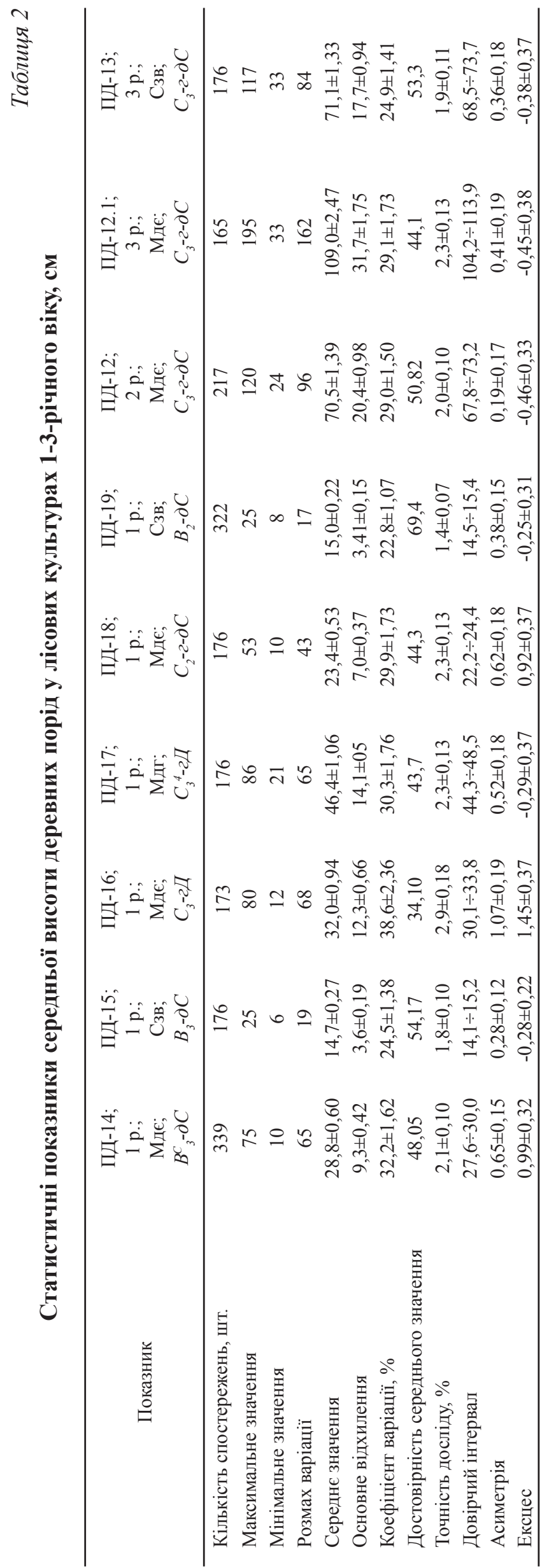

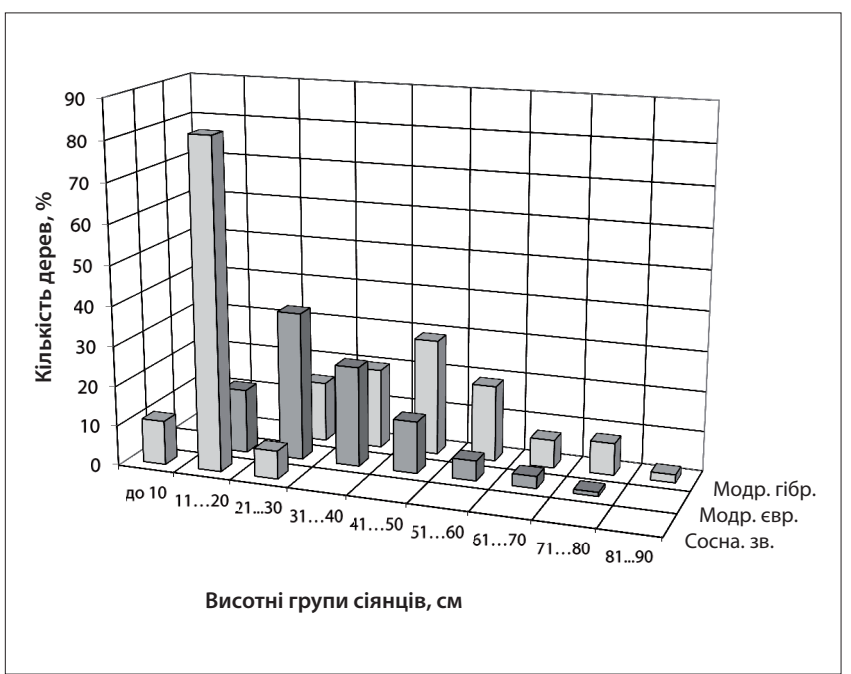

Рис. 1. Розподіл кількості деревець за висотами в 1-річних лісових культурах на пробних ділянках № 15 (Сзв), № 16 (Мдє) та № 17 (Мдг), \%

Результати свідчать, що навіть в 1-річних культурах модрини європейської зафіксовано значні показники висотного приросту $(13,5-17,7$ см) за максимальних значень 35-56 см. У сосни звичайної ці показники помітно менші (відповідно, 5,7-5,9 см та 9-12 см). У 2-річних лісових культурах модрини середній та максимальний показники $Z_{\mathrm{h}}$ суттєво вищі $(41,0$ та 85 см).

У 3-річних культурах є можливість порівняти показники приросту за висотою у модрини та сосни. Так, якщо середні висотні прирости цих порід відрізняються не дуже помітно (43,2 та 35,9 см), то відмінність у максимальних приростах суттєва (102 i $65 \mathrm{~cm})$.

Коефіцієнт варіації у всіх дослідах змінюється в межах 22,1-48,0\%, вказуючи на велику мінливість досліджуваного показника, що, загалом, є закономірним для біологічних об'єктів. Втім, у всіх випадках однорідність вибірки збережена ( $\mathrm{V}<50 \%)$. Дисперсія і стандартне відхилення вказують на помірне і значне розсіювання значень від середньої величини. Отриману точність досліду $(2,0-5,0 \%)$ можна вважати достатньою.

Технологічні особливості створення та особливості росту модрини також вивчали у штучних насадженнях 4-річного віку (табл. 4). Лісові культури досліджено в умовах вологого субору i сугруду.

На пробі № 23 лісові культури створені за схемою 4 p.Сзв $1 \mathrm{p}$. Мде 3 розміщенням садивних місць $2,0-2,5$ x 0,5 м. На пробі № 28 модрину висаджували окремими садивними місцями в ряди сосни і ялини. Сосну і ялину вводили ланками, в основному, iз трьох садивних місць. Розміщення садивних місць дуже густе - 2,0 х 0,5 м.

Порівнюючи показники середньої висоти хвойних порід у 4-річних культурах, встановлено значну перевагу модрини за цим показником над сосною як у суборах (2,1 раза), так і сугрудах (2,7 раза). 


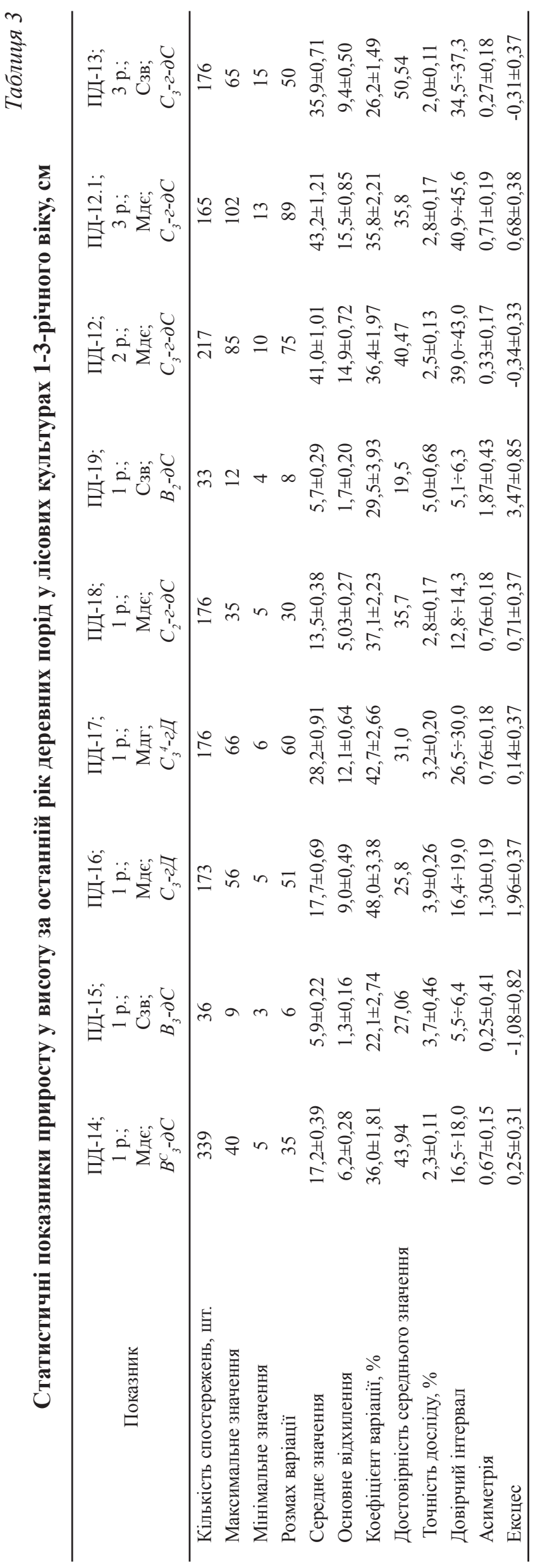

Таку ж перевагу за висотою в умовах $C_{3}$ зафіксовано і над ялиною (див. табл. 4). Дещо меншу перевагу модрини за висотою над іншими хвойними встановлено для максимальних значень. Варіабельність за висотою $є$ найбільшою для модрини, що можна пояснити ії інтенсивним ростом та неоднорідністю використовуваного садивного матеріалу. Для сосни та ялини, інтенсивність росту яких є помітно нижчою, розмах варіації значень за висотою $€$ значно меншим.

Коефіцієнт варіації вказує на середню мінливість висоти у сосни та значну - в ялини та модрини. Проте у всіх випадках однорідність вибірки збережена (14,3-26,0\%). Показник точності досліду $€$ задовільним. У межах вказаного довірчого інтервалу із заданою ймовірністю знаходяться показники висоти досліджуваних порід. Висоти деревних порід характеризуються кривою нормального розподілу $(\mathrm{t}<3)$.

Розподіл дерев хвойних порід за діапазонами висот підтверджує значну перевагу модрини над сосною та ялиною в умовах $B_{3}$ і $C_{3}$. Так, в умовах суборів понад $90 \%$ сіянців сосни звичайної знаходяться у діапазоні висот $0,41-0,80 \mathrm{~cm}$, тоді як у модрини найбільша кількість дерев припадає на діапазон 1,31-1,40 м, а 21 \% дерев знаходиться в діапазоні висот 1,61-1,90 м (рис. 2).

В умовах сугрудів перевага модрини за висотою над сосною і ялиною ще значніша (рис. 3). Якщо дерева сосни та ялини розташовані в подібних висотних групах (максимальна кількість дерев знаходиться у діапазоні 0,61-0,90 м), то найбільша кількість дерев модрини зосереджена у висотних групах 1,91-2,0... 2,41-2,50 м. Деяка кількість дерев модрини (10\%) знаходиться в діапазонах 2,91-3,0...3,11-3,20 м.

Аналіз висотних приростів порід впродовж останнього року відображає загалом тенденцію росту за середньою висотою (табл. 5). Так, в умовах $B_{3}$ висотний приріст модрини в 1,9 раза перевищує такий у сосни, а в умовах $C_{3}$ він у $2,0-2,4$ раза більший, ніж у сосни та ялини.

Коефіцієнт варіації у всіх варіантах змінюється в межах 17,8-31,9\%, вказуючи на середню та значну мінливість досліджуваного показника за збереження однорідності вибірки $(\mathrm{V}<50 \%)$. Отриману точність досліду $(2,8-5,2 \%)$ можна вважати задовільною.

Крива розподілу дерев за висотним приростом характеризується загалом помірною або сильною правосторонньою асиметрією різної крутості. Прирости у висоту дерев за критерієм достовірності $(\mathrm{t}<$ 3) у чотирьох дослідах з п'яти підлягають нормальному розподілу.

У культурах 5-річного віку свіжого та вологого сугрудів перевага модрини над сосною за висотою та висотними приростами зберігається (табл. 6). Під час створення лісових культур (ПД-21) використано ланковий спосіб змішування: 3 п.м. Сзв 1 п.м. Мдє. 
Таблиия 4

Статистичні показники середньої висоти деревних порід у лісових культурах 4-річного віку, м

\begin{tabular}{lccccc}
\hline \multirow{2}{*}{\multicolumn{1}{c}{ Показник }} & \multicolumn{2}{c}{ ПД-23; $B_{3}$-дC } & \multicolumn{3}{c}{ ПД-28; $C_{3}$-г-дC } \\
\cline { 2 - 6 } & $\begin{array}{c}\text { Модрина } \\
\text { європейська }\end{array}$ & $\begin{array}{c}\text { Сосна } \\
\text { звичайна }\end{array}$ & $\begin{array}{c}\text { Модрина } \\
\text { європейська }\end{array}$ & $\begin{array}{c}\text { Сосна } \\
\text { звичайна }\end{array}$ & $\begin{array}{c}\text { Ялина } \\
\text { європейська }\end{array}$ \\
\hline Кількість спостережень, шт. & 23 & 39 & 41 & 41 & 39 \\
Максимальне значення & 1,9 & 1,0 & 3,2 & 1,3 & 1,6 \\
Мінімальне значення & 0,9 & 0,4 & 1,3 & 0,6 & 0,6 \\
Розмах варіації & 1,0 & 0,6 & 1,9 & 0,7 & 1,0 \\
Середнє значення & $1,32 \pm 0,06$ & $0,64 \pm 0,02$ & $2,1 \pm 0,07$ & $0,91 \pm 0,02$ & $0,94 \pm 0,04$ \\
Основне відхилення & $0,28 \pm 0,04$ & $0,12 \pm 0,01$ & $0,48 \pm 0,05$ & $0,13 \pm 0,01$ & $0,24 \pm 0,03$ \\
Коефіціснт варіації, \% & $21,2 \pm 3,26$ & $19,3 \pm 2,26$ & $22,4 \pm 2.59$ & $14,3 \pm 1,61$ & $26,0 \pm 3,14$ \\
Достовірність середнього значення & 22,6 & 32,4 & 28,6 & 44,6 & 24,0 \\
Точність досліду, \% & $4,4 \pm 0,68$ & $3,1 \pm 0,36$ & $3,5 \pm 0,40$ & $2,2 \pm 0,25$ & $4,2 \pm 0,50$ \\
Довірчий інтервал & $1,20 \div 1,43$ & $0,60 \div 0,68$ & $2,0 \div 2,3$ & $0,87 \div 0,95$ & $0,86 \div 1,01$ \\
Асиметрія & $0,36 \pm 0,51$ & $0,76 \pm 0,39$ & $0,44 \pm 0,38$ & $0,28 \pm 0,38$ & $0,79 \pm 0,39$ \\
Ексцес & $-0,87 \pm 1,02$ & $-0,10 \pm 0,78$ & $-0,63 \pm 0,77$ & $0,21 \pm 0,77$ & $0,12 \pm 0,78$ \\
\hline
\end{tabular}

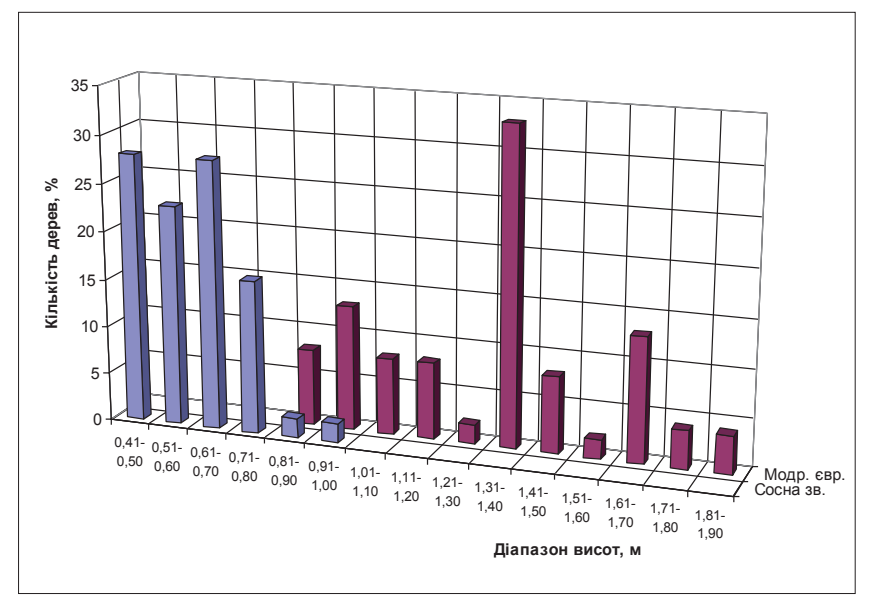

Рис. 2. Розподіл кількості дерев сосни і модрини за висотами в 4-річних лісових культурах на пробі №23 Жовтневого л-ва ДП «Соснівське ЛГ»

в умовах вологого дубово-соснового субору, \%

У насадженні, де закладено пробу №27, модрину вводили в ряди сосни окремими садивними місцями. В культурах присутня як модрина європейська, так і модрина Кемпфера. Обидва види модрини ростуть однаково інтенсивно.

У культурах, де закладено пробу №8.1, використано схему змішування: 1p. Мдє 1р.Ял 3р.Сзв $1 \mathrm{p}$. Ял $з$ початковим розміщенням садивних місць 2,2 х 1,0 м. Дані табл. 6 підтверджують значний розмax значень модрини за висотою. Для сосни, яка росте повільніше, різниця між найбільшою і найменшою варіантами суттєво менша.

Середні висоти дерев за критерієм достовірності $(\mathrm{t}<3)$ у більшості дослідів підлягають нормальному розподілу.

За показником середньої висоти модрина має перевагу над сосною в 1,5-2,2, над ялиною - в 2,63,6 раза. Приблизно таку ж перевагу спостерігаємо і за максимальним значенням. Отже, перевага модрини за висотою над іншими породами є дуже суттєвою.

Для прикладу, представляємо розподіл відносної кількості дерев модрини, сосни та ялини за групами висот на ПД-8.1 (рис. 4). Так, найбільша кількість дерев ялини зосереджена у діапазоні висот 1,0-1,5 м, сосни - 1,6-2,0 м, модрини -3,1-3,5... 4,5-5,0 м. При цьому дерев модрини заввишки до 1,5 м не виявлено, а діапазон 1,6-2,0 м вміщає лише одне дерево. Дерев модрини заввишки 5,1-5,6 м зафіксовано 16 шт.

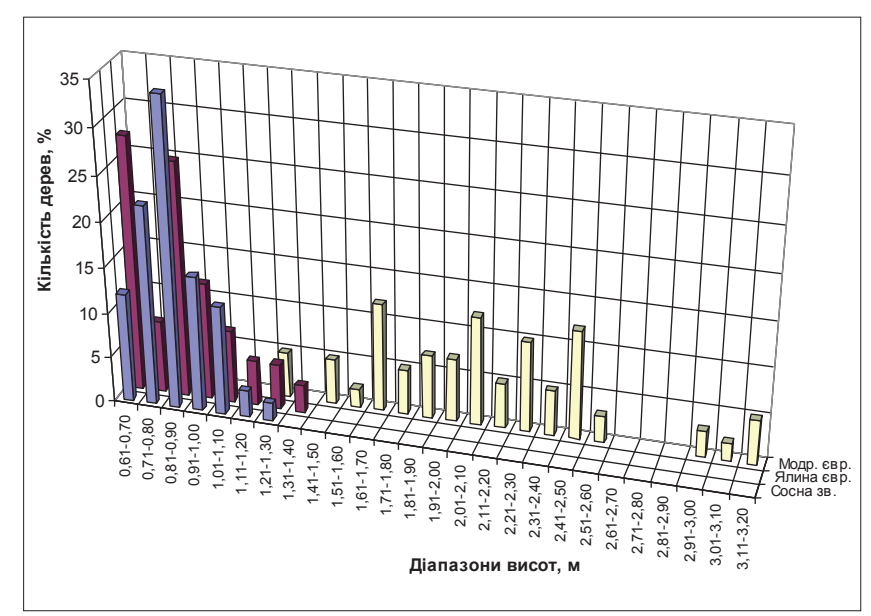

Рис. 3. Розподіл кількості дерев сосни, ялини і модрини за висотами в 4-річних лісових культурах на пробній ділянці №28 Корецького л-ва ДП «Рівненське ЛГ» в умовах вологого грабово-дубово-соснового сугруду, \%

Отже, створення лісових культур за участю сосни і модрини із введенням між ними буферного ряду ялини може бути доцільним заходом, оскільки забезпечується високоінтенсивний ріст хвойних порід, знижується негативний вплив модрини на сосну. 
Статистичні показники приросту у висоту деревних порід за останній рік

Таблиця 5 у лісових культурах 4-річного віку, м

\begin{tabular}{lccccc}
\hline \multirow{1}{*}{\multicolumn{1}{c}{ Показник }} & \multicolumn{2}{c}{ ПД-23; $B_{3}-\partial C$} & \multicolumn{3}{c}{ ПД-28; $C_{3}$-г-дC } \\
\cline { 2 - 6 } & $\begin{array}{c}\text { Модрина } \\
\text { європейська }\end{array}$ & $\begin{array}{c}\text { Сосна } \\
\text { звичайна }\end{array}$ & $\begin{array}{c}\text { Модрина } \\
\text { єрропейська }\end{array}$ & $\begin{array}{c}\text { Сосна } \\
\text { звичайна }\end{array}$ & $\begin{array}{c}\text { Ялина } \\
\text { європейська }\end{array}$ \\
\hline Кількість спостережень, шт. & 23 & 39 & 41 & 41 & 39 \\
Максимальне значення & 0,9 & 0,5 & 1,4 & 0,7 & 0,6 \\
Мінімальне значення & 0,4 & 0,2 & 0,4 & 0,3 & 0,1 \\
Розмах варіації & 0,5 & 0,3 & 1,0 & 0,4 & 0,5 \\
Середнє значення & $0,66 \pm 0,04$ & $0,35 \pm 0,01$ & $0,83 \pm 0,04$ & $0,41 \pm 0,01$ & $0,34 \pm 0,02$ \\
Основне відхилення & $0,17 \pm 0,03$ & $0,09 \pm 0,01$ & $0,26 \pm 0,03$ & $0,07 \pm 0,01$ & $0,09 \pm 0,01$ \\
Коефіціснт варіації, \% & $26,5 \pm 4.18$ & $24,8 \pm 2,97$ & $31,9 \pm 3,86$ & $17,8 \pm 2,02$ & $27,5 \pm 3,34$ \\
Достовірність середнього значення & 18,1 & 25,2 & 20,1 & 36,0 & 22,7 \\
Точність досліду, \% & $5,2 \pm 0,87$ & $4,0 \pm 0,48$ & $5,0 \pm 0,60$ & $2,8 \pm 0,32$ & $4,4 \pm 0,53$ \\
Довірчий інтервал & $0,59 \div 0,73$ & $0,32 \div 0,37$ & $0,75 \div 0,91$ & $0,39 \div 0,43$ & $0,31 \div 0,37$ \\
Асиметрія & $-0,12 \pm 0,51$ & $0,14 \pm 0,39$ & $0,48 \pm 0,38$ & $1,46 \pm 0,38$ & $0,34 \pm 0,39$ \\
Ексцес & $-1,57 \pm 1,02$ & $-1,22 \pm 0,78$ & $-0,88 \pm 0,77$ & $2,65 \pm 0,77$ & $1,23 \pm 0,78$ \\
\hline
\end{tabular}

Таблиия 6

Статистичні показники середньої висоти деревних порід у лісових культурах 5-річного віку, м

\begin{tabular}{|c|c|c|c|c|c|c|c|}
\hline \multirow[b]{2}{*}{ Показник } & \multicolumn{2}{|c|}{ ПД-27; $C_{3}-2-\partial C$} & \multicolumn{2}{|c|}{ ПД-21; $C_{2}-2-\partial C$} & \multicolumn{3}{|c|}{ ПД-8.1; $C_{3}-2-\partial C$} \\
\hline & $\begin{array}{l}\text { Модрина } \\
\text { європей- } \\
\text { ська }\end{array}$ & $\begin{array}{c}\text { Сосна } \\
\text { звичайна }\end{array}$ & $\begin{array}{l}\text { Модрина } \\
\text { європей- } \\
\text { ська }\end{array}$ & $\begin{array}{c}\text { Сосна } \\
\text { звичайна }\end{array}$ & $\begin{array}{l}\text { Модрина } \\
\text { європей- } \\
\text { ська }\end{array}$ & $\begin{array}{c}\text { Сосна } \\
\text { звичайна }\end{array}$ & $\begin{array}{c}\text { Ялина } \\
\text { європей- } \\
\text { ська }\end{array}$ \\
\hline Кількість спостережень, шт. & 32 & 62 & 36 & 77 & 194 & 177 & 149 \\
\hline Максимальне значення & 4,5 & 2,1 & 4,7 & 2,7 & 5,60 & 2,72 & 1,85 \\
\hline Мінімальне значення & 1,5 & 1,1 & 1,5 & 1,3 & 2,00 & 1,12 & 0,70 \\
\hline Розмах варіації & 3,0 & 1,05 & 3,2 & 1,4 & 3,60 & 1,60 & 1,15 \\
\hline Середнє значення & $2,92 \pm 0,13$ & $1,45 \pm 0,03$ & $2,96 \pm 0,11$ & $1,91 \pm 0,04$ & $3,96 \pm 0,06$ & $1,83 \pm 0,04$ & $1,11 \pm 0,02$ \\
\hline Основне відхилення & $0,71 \pm 0,09$ & $0,25 \pm 0,02$ & $0,68 \pm 0,08$ & $0,34 \pm 0,03$ & $0,80 \pm 0,04$ & $0,34 \pm 0,05$ & $0,25 \pm 0,01$ \\
\hline Коефіцієнт варіації, \% & $24,3 \pm 3,22$ & $17,5 \pm 1,62$ & $22,8 \pm 2,83$ & $17,5 \pm 1,45$ & $20,1 \pm 1,06$ & $18,6 \pm 1,11$ & $22,1 \pm 1,34$ \\
\hline $\begin{array}{l}\text { Достовірність середнього } \\
\text { значення }\end{array}$ & 23,2 & 45,0 & 26,3 & 50,1 & 24,3 & 21,4 & 27,8 \\
\hline Точність досліду, \% & $4,3 \pm 0,57$ & $2,2 \pm 0,21$ & $3,8 \pm 0,47$ & $1,99 \pm 0,17$ & $1,4 \pm 0,08$ & $1,4 \pm 0,09$ & $1,8 \pm 0,11$ \\
\hline Довірчий інтервал & $2,68 \div 3,17$ & $1,39 \div 1,51$ & $2,71 \div 3,23$ & $1,84 \div 1,99$ & $3,84 \div 4,07$ & $1,78 \div 1,88$ & $1,07 \div 1,15$ \\
\hline Асиметрія & $0,31 \pm 0,43$ & $0,62 \pm 0,31$ & $0,34 \pm 0,41$ & $0,06 \pm 0,28$ & $-0,27 \pm 0,17$ & $0,06 \pm 0,14$ & $1,04 \pm 0,20$ \\
\hline Ексцес & $-0,74 \pm 0,87$ & $-0,20 \pm 0,62$ & $-0,57 \pm 0,82$ & $-1,04 \pm 0,56$ & $-0,77 \pm 0,35$ & $-0,67 \pm 0,31$ & $0,86 \pm 0,40$ \\
\hline
\end{tabular}

Для приростів у висоту за останній рік у всіх деревних порід загалом виявлено таку ж динаміку, що і для середніх висот: найбільшими вони є у модрини, які в 1,6-2,6 раза перевищують такі у сосни (табл. 7). При цьому у свіжих типах відставання сосни від модрини за цим показником є помітно меншим, ніж у вологих. Мінливість досліджуваної ознаки для обох порід $є$ значною (> 20\%). Разом 3 тим, точність досліду можна вважати достатньою $(2,5-4,4 \%)$.

Висновки. В 1-2-річних лісових культурах значну перевагу за висотою, порівняно із сосною звичайною, має модрина європейська (в 1,5-2,1 раза), а особливо - модрина широколуската (в 3,1 раза). У 3-річних культурах перевага модрини європейської над сосною звичайною за середньою висотою становить 1,5 , за максимальним показником $-1,7$ раза.

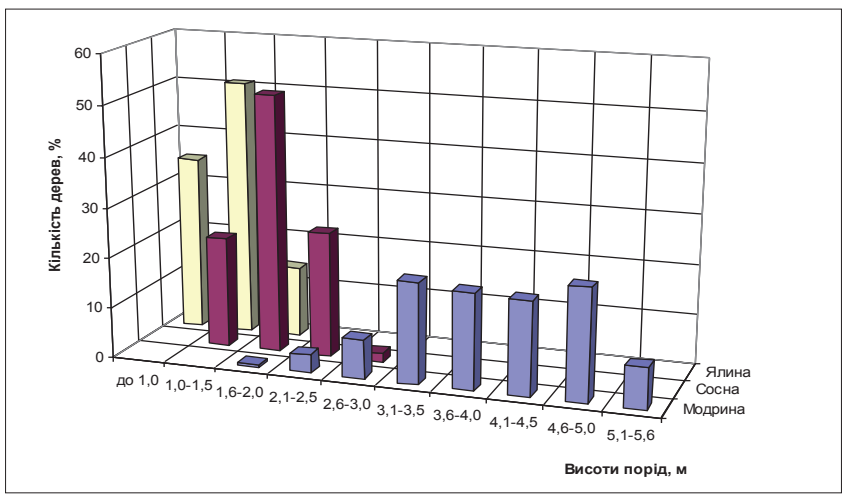

Рис. 4. Розподіл кількості дерев сосни звичайної, ялини європейської і модрини європейської за висотами в 5-річних лісових культурах на пробній ділянці № 8.1 Немовицького л-ва ДП «Сарненське ЛГ» в умовах вологого грабово-дубово-соснового сугруду, \% 
Статистичні показники приросту у висоту за останній рік деревних порід у лісових культурах 5-річного віку, м

\begin{tabular}{lcccc}
\hline \multirow{1}{*}{\multicolumn{1}{c}{ Показник }} & \multicolumn{2}{c}{ ПД-27; $C_{3}$-г-дC } & \multicolumn{2}{c}{ ПД-21; $C_{2}$-г-дC } \\
\cline { 2 - 5 } & $\begin{array}{c}\text { Модрина } \\
\text { європейська }\end{array}$ & $\begin{array}{c}\text { Сосна } \\
\text { звичайна }\end{array}$ & $\begin{array}{c}\text { Модрина } \\
\text { європейська }\end{array}$ & $\begin{array}{c}\text { Сосна } \\
\text { звичайна }\end{array}$ \\
\hline Кількість спостережень, шт. & 32 & 62 & 36 & 77 \\
Максимальне значення & 1,6 & 0,7 & 1,3 & 0,8 \\
Мінімальне значення & 0,5 & 0,15 & 0,5 & 0,3 \\
Розмах варіації & 1,1 & 0,55 & 0,8 & 0,5 \\
Середнє значення & $0,97 \pm 0,04$ & $0,37 \pm 0,01$ & $0,86 \pm 0,03$ & $0,54 \pm 0,01$ \\
Основне відхилення & $0,24 \pm 0,03$ & $0,11 \pm 0,01$ & $0,20 \pm 0,02$ & $0,12 \pm 0,01$ \\
Коефіціснт варіації, \% & $24,8 \pm 3,28$ & $29,8 \pm 2,91$ & $23,0 \pm 2,85$ & $22,2 \pm 1,87$ \\
Достовірність середнього значення & 22,8 & 26,4 & 26,1 & 39,5 \\
Точність досліду, \% & $4,4 \pm 0,58$ & $3,8 \pm 0,37$ & $3,8 \pm 0,48$ & $2,5 \pm 0,21$ \\
Довірчий інтервал & $0,89 \div 1,06$ & $0,34 \div 0,40$ & $0,79 \div 0,92$ & $0,51 \div 0,57$ \\
Асиметрія & $0,39 \pm 0,43$ & $0,50 \pm 0,31$ & $-0,04 \pm 0,41$ & $-0,02 \pm 0,28$ \\
Ексцес & $0,06 \pm 0,86$ & $0,44 \pm 0,62$ & $-0,76 \pm 0,82$ & $-0,85 \pm 0,56$ \\
\hline
\end{tabular}

Середні прирости у висоту в 1-річних культурах модрини європейської помітно вищі, ніж у сосни звичайної (в 2,4-3,0 рази). У 3-річних культурах перевага модрини над сосною за цим показником зберігається (в 1,3 -1,6 раза).

У 4-річних культурах перевага модрини над сосною за висотою у вологих суборах становить 2,0 , а над сосною та ялиною у вологих сугрудах $-2,3-2,4$ раза. У 5-річних лісових культурах за показником середньої висоти модрина має перевагу над сосною в 1,5-2,2, над ялиною - в 2,6-3,6 раза.

Вологий тип лісорослинних умов є оптимальним лише для ялини, тоді як модрина та сосна краще ростуть у свіжих типах. Однак в умовах $C_{3}$ сосна, а особливо модрина, також відзначаються дуже високою інтенсивністю росту.

Під час створення лісових культур використано переважно схему розміщення садивних місць - 2,0х 1,0 м 3 розрахунку на можливий відпад модрини. Однак він виявився незначним (4-7\%), тому крок садіння для породи, враховуючи її високу інтенсивність росту, є недостатнім. Початкова густота культур 5,0 тис. шт./га для швидкорослої модрини є занадто великою.

Враховуючи підтип лісорослинних умов, в умовах свіжих і вологих сугрудів крок садіння в рядах модрини доцільно запровадити в межах 1,5-2,0 м, а в умовах свіжих і вологих суборів - 1,3-1,5 м.

\section{Бібліографічні посилання}

Belelia, S. O. (2012). Larch in the forest plantations of Rivne region. Proceedings of the 1st International Scientific and Practical Conference "Natural Resource Complex of Western Polissya: History, Status and Prospects for Development", 13-14. Berezne,
Ukraine: higher educational institution «The Nadsluchanskyi Institute» (in Ukrainian).

Belelia, S. O. (2013). Distribution of larch in forest plantations of Rivne and Volyn regions. Scientific bulletin of the Ukrainian National Forestry University, 23.6, 10-17 (in Ukrainian).

Debryniuk, I.M. (2003). Features of the formation of root systems of Larix decidua Mill. in forest crops of the Western Forest-steppe of Ukraine. Scientific bulletin of the Ukrainian State Forestry University, 13.1, 30-43 (in Ukrainian).

Debryniuk, I. M. (2013). Forest crops involving pine and larch as an example of high-yielding plantations of Western Polissya. Proceedings of the 63rd scientific and technical conference of the academic teaching staff, scientists, doctoral students and postgraduates of the UNFU on the results of research activity in 2012 «Scientific basis for enhancing productivity and biological stability of forest and urban ecosystems», 33-37. Lviv, Ukraine: Ukrainian National Forestry University (in Ukrainian).

Dospekhov, B.A. (1979). Field experiment techniques (with the basics of statistical processing of research results). Moscow: Kolos (in Russian).

Gerushynsky, Z.Yu. (1987). Manual for the identification offorest types in the Ukrainian Carpathians. Lviv: Regional Printing Publishing House (in Russian).

Girs, O.A., Manita, O.H., Myronjuk, V. V., Swingchuk, V.A., \& Berezovsky, L. M. (2013). Forest Inventory Directory. Kiev: Vinichenko Publishing House (in Ukrainian).

Goroshko, M.P., Myklush, M.I., \& Khomyuk, P.G. (2004). Biometrics. Lviv: Kamula (in Ukrainian).

Gorshenyn, N. M., \& Buteyko, A. I. (1962). Identification of types of site conditions. Lviv: High School (in Ukrainian). 
Grom, M.M. (2005). Forest assessment: Educational manual. Lviv: Ukrainian National Forestry University (in Ukrainian).

Instruction on design, technical acceptance, recording and evaluation of forest-cultural objects quality. (2010). Approved by the order of the State Forestry Committee of Ukraine of 19.08.2010, №260. Kyiv: Ukraine (in Ukrainian).

Krasnov, V. P., Orlov, O. O., \& Vedmid, M. M. (2009). Atlas of indicator-plants and types of site conditions in Ukrainian Polissya. Novograd-Volynsky: NOVOgrad (in Ukrainian).

Miroshnikov, V.S., Trull, O.A., Ermakov, V.E., Dolsky, L. V., \& Kostenko, A. H. (1980). Directory of the forest cruiser. Minsk: Harvest (in Russian).

Ostapenko, B.F., \& Tkach, V.P. (2002). Forest typology. Kharkiv: Kharkiv State Agrarian University (in Ukrainian).

Parakin, V. V., \& Mosina, L. V. (1988). Comparison of radial increments of common pine and European larch under conditions of their co-growing in the experimental forest of the Timiryazev Agricultural Academy. Collection of scientific works: Forest science, forestry and forest cultures, 12, 13-18 (in Russian).

Pisarenko, A. I., \& Merzlenko, M. D. (1990). Creation of artificial forests. Moscow: Agroindustrial publishing house (in Russian).

Vorobiev, D. V., \& Ostapenko, B. F. (1979). Forest-typological foundations of silviculture. Kharkiv: Kharkiv Agricultural Institute (in Russian).

Yanushko, A. D., \& Zabello, K.L. (1969). Influence of pine and larch cultures on the fertility of sod-podzolic soils on a powerful silty loam. Collection of scientific works: Forest science and forestry, 2, 36-40 (in Russian).

\section{Технология создания и особенности роста сосны и лиственницы в лесных культурах Западного Полесья}

\section{Ю.М. Дебринюк' , С. О. Белеля²}

Лиственницу в лесных культурах Западного Полесья чаще всего культивируют в смешанных насаждениях с участием сосны обыкновенной. Принимая во внимание необходимость повышения фак-

Дебринюк Юрий Михайлович - действительный член Лесной академии наук Украины, академик-секретарь ЛАН Украины, доктор сельскохозяйственных наук, профессор кафедры лесных культур и лесной селекции. Национальный лесотехнический университет Украины, ул. генерала Чупринки, 103, г. Львов, 79057, Украина. Тел.: 032-235-30-12, +38-067-195-78-36. E-mail: debrynuk_ju@ukr.net

Белеля Сергей Александрович - член-корреспондент Лесной академии наук Украины, кандидат сельскохозяйственных наук, директор Государственного предприятия «Сарненское ЛХ» Ривненского областного управления лесного и охотничьего хозяйства, ул. Гоголя, 34, г. Сарны, 34500, Украина. Тел.: +38-03655336-69, +38-03655-355-21; E-mail: sarnylis@sowa.com.ua тической производительности лесных насаждений до потенциального уровня, повышение биотической устойчивости сосновых насаждений, введение в искусственные насаждения региона ограниченного количества лиственницы является актуальной проблемой.

Объектом исследований были искусственные насаждения с участием Pinus sylvestris L. и видов рода Larix L. в связи с технологией их создания и выращивания. Предмет исследования - технологические элементы создания и рост главных и сопутствующих пород в 1-5-летних лесных культурах.

Цель исследований заключалась в сравнении особенностей роста по высоте сосны обыкновенной и различных видов лиственницы в лесных культурах относительно бедных (субори) и относительно богатых (сугруды) свежих и влажных типах лесорастительных условий. Главными породами являются Pinus sylvestris L., Larix decidua Mill., Larix eurolepis H., сопутствующей - Picea abies L. [Karst.]. Исследовали искусственные насаждения, произрастающие на территории лесного фонда Государственных предприятий «Сарненское ЛХ», «Ривненское ЛХ» и «Сосновское ЛХ» Ривненского областного управления лесного и охотничьего хозяйства.

Установлено, что в 1-летних культурах значительное преимущество по высоте по сравнению с сосной обыкновенной, имеет Larix decidua (в 1,52,1 раза), а особенно - Larix eurolepis (в 3,1 раза). В 3-летних культурах преимущество лиственницы европейской над сосной обыкновенной по средней высоте составляет 1,5 , по максимальному показателю - 1,7 раза.

Средние приросты по высоте в 1-летних культуpax лиственницы европейской заметно выше, чем у сосны обыкновенной (в 2,4-3,0 раза). В 3-летних культурах преимущество лиственницы над сосной по этому показателю сохраняется (в 1,3-1,6 раза).

В 4-летних культурах преимущество лиственницы над сосной по высоте во влажных суборях составляет 2,0 , а над сосной и елью во влажных сугрудах - 2,32,4 раза. В 5-летних лесных культурах по показателю средней высоты лиственница имеет преимущество над сосной в 1,5-2,2, над елью - в 2,6-3,6 раза.

Влажный тип лесорастительных условий является оптимальным только для ели, тогда как лиственница и сосна лучше растут в свежих типах. Однако, по результатам исследований, во влажных относительно богатых типах лесорастительных условий сосна, а особенно лиственница, отмечаются достаточно высокой интенсивностью роста.

При создании лесных культур использована преимущественно схема размещения посадочных мест $-2,0$ x 1,0 м из расчета на возможный отпад лиственницы. Однако он оказался незначительным (4-7\%), в связи с чем шаг посадки для породы, учитывая ее высокую интенсивность роста, недостаточен. Начальная густота культур в 5,0 тыс. шт./га для быстрорастущей лиственницы также слишком большая.

Учитывая подтип лесорастительных условий, в свежих и влажных сугрудах шаг посадки в рядах 
лиственницы целесообразно установить в пределах 1,5-2,0 м, а в условиях свежих и влажных суборей $-1,3-1,5 \mathrm{M}$.

Ключевые слова: лесные культуры 1-5-летнего возраста, рост по высоте, Pinus sylvestris L., Larix decidua Mill., Larix eurolepis H., Picea abies L. [Karst.]

\section{Technology of planting and growth peculiarities of pine and larch plantations in the Western Polissya}

\author{
lu. Debryniuk', S. Belelia²
}

Larch in forest plantations of the Western Polissya is mostly cultivated in mixed plantations with the Scots pine participation. Taking into account the need to increase the actual productivity of forest plantations to a potential level, the increasing the biotic stability of pine plantations and introducing a limited amount of larch into plantations of the region is considered as a topical problem.

The object of the research were the plantations with the participation of Pinus sylvestris L. and species of the genus Larix L. in connection with the technology of their planting and cultivation. The technological elements of the planting and growth of the main and accompanying species in 1-5-year-old forest cultures the subject of were the research.

The aim of the research is to compare the characteristics of growth by height of Scots pine and various species of larch in forest cultures of relatively poor (fairly infertile pine site type) and relatively rich (fairly fertile site type) of fresh and moist types of forest growing conditions. The main species are Pinus

Iurii Debryniuk - full member of the Forestry Academy of Sciences of Ukraine, Academician-Secretary of the Ukrainian Forestry Academy of Sciences, Doctor of Agricultural Sciences, Professor of the Department of Forest Crops and Forest Selection. Ukrainian National Forestry University. 103, General Chuprynka st., 103, Lviv, 79057, Ukraine. Tel .: 032-235-30-12, + 38-067-195-78-36. E-mail: debrynuk_ju@ukr.net

Sergiy Belelia - Corresponding Member of the Forestry Academy of Sciences of Ukraine, PhD in Agricultural Sciences, Director of the Sarny State Forestry Enterprise. Department of Forestry and Hunting, Rivne region. 34, Gogol st., Sarny, 34500, Ukraine. Tel .: + 38-03655336-69,+38-03655-355-21; E-mail: sarnylis@sowa.com.ua sylvestris L., Larix decidua Mill., Larix eurolepis H., associate species - Picea abies L. [Karst.] We studied the plantations which are growing on the territory of the forest fund of the Sarny State Forestry enterprises, the Rivne Forestry Enterprise and the Sosnivka Forestry Enterprise of the Rivne Regional Forestry and Hunting Administration.

It was found that among the 1-year-old cultures, a significant advantage in height comparing to Scots pine, has Larix decidua (in 1.5-2.1 times), and especially - Larix eurolepis (3.1 times). In 3-year-old cultures, the advantage of the European larch over the Scots pine in average height is 1.5 times, in terms of maximum height -1.7 times.

The average increment in height in the one year-old cultures of European larch is noticeably higher than in Scots pine (2.4-3.0 times). In 3-year-old cultures, the advantage of larch over the pine on this indicator remains the same (in $13-1.6$ times).

In 4-year-old cultures, the advantage of larch over pine in height in moist fairly infertile pine site type is 2.0, and the advantage over pine and spruce in moist fairly fertile site types - 2.3-2.4 times. In 5-year-old forest cultures, in terms of average height, larch has an advantage over pine in 1.5-2.2, over spruce - in 2.6-3.6 times.

A moist type of forest growth conditions are optimal only for spruce, whereas larch and pine grow better in fresh types. However, according to the results of research, pine, and especially larch, are stand out by rather a high growth rate in moist relatively rich types of forest-growing conditions.

When planting forest crops, the following scheme of the planting spots was mainly used $-2.0 \times 1.0 \mathrm{~m}$, based on the possible mortality of larch. However, the mortality rate was insignificant (4-7\%), in connection with which the plant spacing for the species, given its high growth rate, is insufficient. The initial crops density with 5.0 thousand pieces / ha for fast-growing larch is also too large.

Taking into account the subtype of forest growing conditions, it is recommended to the plant spacing in rows of larch in fresh and moist fairly fertile site type set within the range of 1.5-2.0 m, and in the conditions of fresh and moist fairly infertile site types 1.3-1.5 m.

Key words: forest plantations, growth height, Pinus sylvestris L., Larix decidua Mill., Larix eurolepis H., Picea abies L. [Karst.] 